Croatian International Relations Review

XXVI (87) 2020,

6-31

DOI 10.37173/

cirr.26.87.1

UDC 005.7:327:061.1EU
-

\section{On the Norms and Habits \\ of the European Union as a \\ Meta-organisation $^{*}$}

\section{Marina V. Strezhneva}

Primakov National Research Institute of World Economy and International Relations (IMEMO), Russia

m.strezhneva@imemo.ru

ORCID: 0000-0002-6561-4367

\section{Abstract}

With the aim of methodological reflection, this article analyses

Key words:

European Union;

International

Relations;

Organisation

Theory; Tektology;

Resilience the three approaches (realist, constructivist and relational) in international relations theory most commonly employed to study foreign policy and the global influence of the European Union. Pivotal notions such as 'agenc $\gamma^{\prime}$, 'identit $\gamma^{\prime}$, 'norms', 'system' and 'practice' provide us with navigation points between these approaches, enabling us to achieve a clearer impression of the many different meanings these terms can contain. These meanings, in their turn, fix the direction, limitations and scope of any concrete theoretic analysis. This article is meant to draw particular attention to Bourdieuvian practice theory and Alexander Bogdanov's tektology as two differing variants of relationism, with a view to overcoming certain deficiencies in application to the studies of the EU of methodological individualism, as employed in more 'traditional' theories. To illustrate the relationalist way of theorising when dealing with the paradoxes of the EU external policies and global role, a follow-up interpretation, based on tektology, is given in conclusion to the resilience turn in the EU global strategy.

* Acknowledgements

The article was prepared within the project "Post-crisis world order: challenges and technologies, competition and cooperation" supported by the grant from the Ministry of Science and Higher Education of the Russian Federation program for research projects in priority areas of scientific and technological development (Agreement No 075-15-2020-783). 


Croatian
International
Relations
Review
-
CIRR
-
XXVI (87) 2020,
$6-31$

Croatian

International

Relations

XXVI (87) 2020,

\section{Introduction}

The external relations of the European Union (EU) extend to almost every, and even the most remote, place on Earth. The EU also possesses a profuse arsenal of foreign policy instruments - diplomatic, economic and (to a lesser extent), military. Yet the Union has not acquired the complete array of foreign policy responsibilities as those enjoyed by sovereign states. One of the most important specialisms carried out by the EU in the international arena, and to some extent fitting the Normative Power Europe (NPE) description of the EU (Manners 2002), consists of 'exporting' abroad original techniques to foster intergovernmental cooperation, global governance and regional integration. It thus seems problematic to our full comprehension of the global role and international status of the EU if we rely exclusively on the more traditional theories of International Relations (IR), either realist or constructivist, which are often state-centric. Yet to depend instead on theories of regional integration could equally be ill-judged. These theories, including an alternative, a critical integration theory, embracing some recent developments in IR theory, notably the structure-agency debate (Bulmer and Joseph 2016), are namely more focused on what goes on within the EU, not beyond its borders or with the EU in the global context.

The wider sphere of IR never stays unchanged: promising theories and methodologies are continually developing and progressing. Inter alia, recent years have seen a growing influence exerted by the theoretical heritage of the French sociologist, Pierre Bourdieu (Adler-Nissen 2013). As the purpose of this study is not to assess whether or not the EU 'really' is an international actor of some particular kind or definition, but to focus instead on the issue of perceived (in)adequacy of its activities in respect to the evolving international 'environment' (Hill 1993; Börzel, Risse 2009; Veebal, Markus 2018), Bourdieuvian practice theory seems particularly relevant (Adler and Pouliot 2011). In the meantime, much less noted organisation theory (tektology) by Russian revolutionary and analyst Alexander Bogdanov could also turn out to be of use when discussing today the pertinence of practice turn in international relations for the study of the EU role (Bogdanov 1984). With such considerations in mind, this article attempts to take stock of the current IR theories being employed to study the EU's international influence, so as to deliver some additional methodological reflection with the 


\begin{abstract}
Croatian
International

Relations

Review

CIRR

$-$

XXVI (87) 2020,

6-31

intention of stressing the importance of designedly describing the world with and around the EU in terms of relations, primarily or exclusively (Schneider 2015).

The article consists of five key parts: the immediate section following is devoted to detecting a problematic aspect in the existing conceptualisations of the EU as an international actor/ agent in organisational terms. The two subsequent sections discuss the specifics of prevalent realist and constructivist IR approaches. The fourth part illustrates the ways some putative 'breaches' can be rectified with the assistance of Bourdieu's epistemological relationalism. The fifth and concluding section discusses Bogdanov's empiriomonist (phenomenological) methodology (Gorelik 1983) as potentially helpful in adjusting our understanding of the European Union's relations to the outer world.
\end{abstract}

\section{Conceptualising the EU}

As is well known, due to the EU's unclear form as a political entity, it is rather challenging to find an adequate analytical framework to deal with it. As far as it concerns its political form, the EU is unique (sui generis) - something between a state and an international organisation. On the one hand, when regarded as a (quasi)state, the EU, more often than not, is interpreted as a prime example of the post-modern state: "more pluralist, more complex, less centralised than the bureaucratic modern state" (Cooper 2000: 31). Yet some authors prefer to stress the resemblance of the Union to 'normal' states (Kreppel 2012). Equally, the EU can be cast as an international organisation, albeit a distinctive one - closely conforming to the type of meta-organisation (MO) featured by Goran Ahrne and Nils Brunsson (Ahrne and Brunsson 2008). MOs started to perform as the agents of global governance (Ahrne, Brunsson and Kerwer 2016: 5) and could thus no longer be adequately treated as simple arenas for states' representatives to interact in. Meta-organisations bear some resemblance to biological communities (such as swarms' or ants' colonies) (Tautz and Heilmann 2008). At the same time, we can speak of them as a unique technology for organising inter-linkages and interactions among a group of states. One way or another, it might be useful, as Bogdanov's tektology invites us to do, to correlate our search for new knowledge about the EU as a MO 


Croatian
International
Relations
Review
-
CIRR
-
XXVI (87) 2020,
$6-31$

Croatian

International

Relations

XXVI (87) 2020, with our understanding of the (system) attributes of the EU as a complex object under study.

In classical organisation theory (OT) organisations are defined as units of people (not of states), enjoying exclusive rights as its members, and acting on the basis of established principles and rules in pursuance of collective goals. Traditional OT is more focused on exposing the structural characteristics of decisionmaking within organisations, meaning not only their formal structures but also their informal and network-type interlinkages, along with socio-cultural and cognitive aspects of organisational design. In this respect, Zuzana Murdoch (2015) has signalised the added value of OT to the sphere of EU studies. This theory also seeks to expose the relations between organisations in particular environments, as well as the influence of the institutional environment over the behaviour and development of organisations.

As a distinctive political system with similarities to both states and international organisations, the European Union has given birth to the concept of multi-level governance - MLG (Hooghe and Marks 2001). The applicability of this concept to the study of the Common Foreign and Security Policy of the EU, despite the state-centric features of the CFSP, has been demonstrated by Michael Smith (Smith 2004). Yet the EU, as a multi-level governance system, is a political 'subject' of an unusual kind. It is transnational, has no central government of its own, and takes shape behind the backs of national governments.

The introduction of MLG in the EU caused the diffusion of regulating authority in the system. Trends of opaque bargaining are in play, involving different levels of governance. Due to that, the key values of democratic governance can be sacrificed by the governing elite, time and again, to achieve trade-offs in a closer circle, to find intergovernmental consensus or to improve efficiency in supranational decision-making (Peters and Pierre 2004: 85). The subsidiarity principle is of particular importance for the MLG macroregional arrangement, as it provides a stress on limiting the role of states (they should interfere as little as possible in the performance of communes and societies). At first sight, this principle might seem univocal. It was introduced in the EU to avert excessive supranational centralisation. In one respect, it allows member states to retroact the unwelcome interference of supranational institutions in 


Croatian
International
Relations
Review
-
CIRR
-
XXVI (87) 2020,
$6-31$

Croatian

International

Relations

Review

CIRR

XXVI (87) 2020 $6-31$ their domestic affairs. On another level, European decisionmaking practice becomes involute. Supranational institutions can hypothetically take advantage of subsidiarity for purposes other than it was intended for - by «hiding» behind it in order to refrain from urgent action in a complicated situation. At the same time, subsidiarity has a democratic dimension. It reflects considerations related to the extent of the proximity of citizens to the decision-making centres and the right to selfrule (Strezhneva 2018: 21-7).

The external policy and involvement of the EU in global policy formulations are being realised not only via the intergovernmental CFSP but, more importantly, as part of supranational and transnational governance, elaborated within the EU system and spilling over ad extra. The impulse of the multi-level EU 'system', whether out of expediency or as a reflexive reaction, to externalise itself can meet with resistance, both inside the Union and in third countries, once more accustomed forms of another actor's political existence become challenged by the changes it envisions.

To analyse the foundations of subjecthood, or agency (the term he himself preferred), Bourdieu introduced the concept of habitus (dispositions, habits and inclinations) as a semiconscious, but lasting, orientation that people have, forming the basis of their perceptions and experience (Bourdieu 1977: 78). Habitus involves "trained capacities and structured propensities to think, feel, and act in determinate ways, which then guide (agents - M.S.) ...in their creative responses to the constraints and solicitations of their extant milieu" (Wacquant 2005: 317). If seen in this light, the behaviour of the EU in the international arena might be, more likely than not, driven by the urge of the European ruling elite to achieve better correspondence (isomorphism, to be discussed later) between the Union and its (mostly state-centric) international milieu, rendering the surrounding international space 'more habitable' to it. According to Bogdanov's more general view, each human collective, irrespective of its origin, would tend to organise the surrounding space in order to render it habitable.

When in need to clarify the international identity of the EU, experts have resorted to different, and sometimes rival, terms. These include civilian power (Duchene 1972; Börzel, Risse 2009: 5), structural power (Keukeleire and Delreux 2015) and 


Croatian
International
Relations
Review
-
CIRR
-
XXVI (87) 2020,
$6-31$

Croatian International Relations Review

\section{CIRR}

6-31 (neo)empire (Kassab 2018: 141-59). Among these - and most useful for the purposes of the present article - is the notion of Market Power Europe (MPE) (Damro 2012, 2015), and the already-mentioned NPE. These highlight the specific resources (or capital, in Bourdieuvian parlance) of the Union as a nontraditional international agent.

The concept of NPE endows the European Union with the ability to correct the widely adopted understanding of 'normality' in global affairs. Ian Manners finds the roots of this ability in the EU's unique political form as a hybrid of national and international governance (Manners 2002: 240). The hybrid political form, according to Manners, predetermines the disposition of the Union (the collective habitus of the European elite) to change pre-existing (state-centric) norms in the international arena. In his view, it is impossible for the EU to behave differently, as to forgo its own transformative power in international relations would be equal to sacrificing the unique character of the Union (Manners 2002: 241-2).

Manners describes in detail how the external transmission of European norms can occur: either being spread through the influence of the example that the European Union gives to the rest of the world, or through institutionalisation (by forming a matrix of relations with other international actors), or through its immediate international presence (EU representations in third countries and international organisations). In this regard that "the EU's attempt to invoke normative commitments from China and Russia has not been well-received" (Aggestam 2009: 30) is not directly relevant. It is more relevant, though, for those who are inclined to regard China and Russia as belonging to an international system, where the post-modern EU, with its ethical stance, serves as the organising centre. With China and/ or Russia purportedly refuting such a perception, the European Union nevertheless can perfectly remain the embodiment of NPE in this understanding - as long as it is willingly accepted as such by a myriad of other international actors, not necessarily states, thus legitimising this (presumably alternative to the older one) post-modern international system.

Anyway, there are possible ways to interpret the normative powers of the EU, drifting away from Manners' original template in different directions. One possible way is to view them as part of the Union's specific identity. Thus, according to Andre Gerrits, 


Croatian
International
Relations
Review
-
CIRR
-
XXVI (87) 2020,
$6-31$

Croatian

International

Relations

Review

CIRR

XXVI (87) 2020 $6-31$
NPE "has become a grand narrative, an answer to the ever more pressing need to bestow an identity on Europe - legitimacy through foreign policy" (Gerrits 2009:4). Paradoxically, this way prescribes external behaviour for the EU which third countries may find excessively Eurocentric (Bicchi 2006) - with the result being a decay in the EU's self-imposed identity in the long run (Pavlova, Romanova 2017). Another way would be to stress the more or less stable ontological potential of the EU (its relatively high ability to change international norms), which is less questionable. Thus understood, the EU's normative power can be exercised in competition with other international actors (such as the USA, China, Russia, Great Britain, and Germany), though it is not necessarily benign for these other actors.

In sociology, growing convergence between the processes and structures of one organisation with those in another as a result of imitation under pressure or in the course of autonomous development - and when experiencing the same limitations - is called isomorphism (Hannan, Freeman 1977). It is broadly defined as the propensity of organisations to resemble other organisations functioning in the same environment (Param and Bilimoria 1997). While the NPE concept takes for granted the transformative influence of the EU, there are in actuality two possible options to achieve closer isomorphism between the Union and its predominantly state-centric international milieu: in addition to attempting to change the milieu, the other possibility is for the EU to change itself (in accordance with the demands of state-centrism) and to become a traditionally 'normal' state. In this way, the survival (external legitimacy) of the EU would be secured at the expense of losing its unique post-modern features. However, this option is the less likely one, given the current limitations to further centralisation in the EU.

The MPE or Regulatory Power Europe (Goldthau and Sitter 2015) models are interpretations, alternative to NPE. These models see the EU as exercising its power by externalising marketrelated policies and regulations in particular. The MPE presents the EU as a global regulator, positioning itself as a key actor of 'managed globalization', which relies on multilateral rules and international organisations (Abdelal and Meunier 2010).

As it turns out, both Manners and Damro find the most important 'capital' in the EU's external policy in its ability to 


\begin{abstract}
Croatian
International

Relations

Review

$-$

CIRR

$-$

XXVI (87) 2020,

6-31

export norms. In the case of the NPE, the norms in question emerge as constitutive: creating or defining an (international) activity, they provide (or are expected to provide) for the establishment of new institutional facts (contracts) and may lead to modification of the wider international system. In the MPE, we are dealing with regulative norms, the performance of direct duties, and conditional prohibitions and authorisations (Boella and van der Torre 2004). The NPE and MPE dynamics can in practice alternate and intertwine, bringing to life a Normative Market Europe (Geeraert and Drieskens 2017).
\end{abstract}

\section{Realism}

Statism (state-centrism), unlike wider notions such as interests and power, is not an integral reference point in the theory of political realism. Instead, its third major premise, along with these two, is not state-centrism, but groupism. The idea of groupism is that, in order to ensure their security and survival, people tend to adhere to group solidarity and to develop institutionalised practices that encourage them to depend on their own groups (Wohlforth 2008), or collective actors. The definition of a collective actor can reasonably include not just states, but also supranational integrated communities (such as the EU). The EU can thus be accepted in the realist framework as an international actor with its own interests and its own powers.

Neorealism inherently treats the EU as one of the subsystems of the international system (Hoffmann 1966). Yet, while sharing the broad systemic vision, many realist-minded authors are ready to accept the EU as an international actor in its own right, though deploying different explanations and interpretations for its specific nature. ${ }^{1}$ One of these approaches focuses on the EU's use of soft power (Michalski 2005; Kugiel 2017).

Both analysts and EU officials agree that the consistent employment of soft power instruments is one of the EU's main strengths in the international sphere, given the rich repertoire of civilian tools it possesses. At the same time, the EU's soft power has its limitations, as demonstrated by present-day developments in Ukraine, meaning that it does not give the

1 A Bourdieuvian critique of the neorealist understandings of the international system was provided by Richard Ashly (1984). 


Croatian
International
Relations
Review
-
CIRR
-
XXVI (87) 2020,
$6-31$

Croatian

International

Relations

Review

XXVI (87) 2020,

$6-31$

EU much ability to resolve the conflict. It should be noted that the EU does have hard power as well, coming first via its crisis management capabilities and sanctions policies, which are being applied more widely and consistently as time passes.

In sum, soft power as a description does not fully define the EU's role and has become a less accurate description under the present circumstances in Europe. As former Commission President Jean-Claude Juncker admitted in 2016, "soft power is no longer enough in the EU's increasingly dangerous neighbourhood" (Juncker 2016: 18), and in this context, the boundaries between what is supposed to constitute its hard and soft power have become ever more fuzzy. ${ }^{2}$

Another way to account for the EU's specific character in realist fashion is in addressing the milieu goals, an approach proposed by Arnold Wolfers (1962). This means shaping the environmental conditions (goals in the fields of development, ecology, labour rights and public health) within which international actors operate, as contrasted with possession goals (access to energy, trade preferences and migration controls). In this way, power is understood as the capacity to influence someone or something. The 'milieu goals' concept is usefully pointing to the interdependence of (national, regional) interests and global goals. According to Nathalie Tocci:

Furthering milieu goals may actually contribute to the advancement of possession goals. However, unlike possession goals, milieu goals are pursued consistently over time, and not only at the time when they also represent immediate possession goals (Tocci 2007: 4).

Yet another conceptual route is offered by the position of neoclassical realism, or modified realism, made distinctive by its acceptance of state-level causal variables. According to Dmitry Vasfilov, who applied this schema, the post-Soviet competition between Russia and the EU is higher than required by the international system (perceived by him, as a realist, as consisting mostly of states) because, due to the influence of a number of internal factors, elites in both Russia and the EU are unable to adequately understand and process the signals sent

2 As formulated by Andreas Goldthau and Nick Sitter (2015: 109-16), in the politics of oil, gas, and climate change, the EU exercises two intermediary forms of power simultaneously - passive hard power and conditional soft power, or soft power with a hard edge. 


\begin{abstract}
Croatian
International

Relations

Review

-

CIRR

$-$

XXVI (87) 2020,

6-31

by the 'objective' system (Vasfilov 2014).

The above variations notwithstanding, present-day realist approaches tend not to reflect on the underlying state-centrism of realism per se. This leads to the underestimation by realistminded researchers of the unique character of the European Union's existence, as a decentralised polity, itself being an important factor, influencing the EU's relations with the outside world. The roots of the statist orientation can be found in the realist reification of geopolitics as a domain separable from 'the social' (Davenport 2013).
\end{abstract}

\section{Constructivism}

The uniqueness of the EU as a global actor is often supposed to consist, at least to some extent, in its ability to create new meanings and perceptions in the international arena. Because of this, constructivism may be a more suitable model for studying the EU's international role. Constructivists interpret the world as being created by actors through internal models (constructs). As an analytical approach, constructivism is an umbrella for many different currents, yet constructivism does not always tear away from state-centrism.

Alexander Wendt, a leading constructivist in IR, pointed out that intersubjective meanings determined cause-and-effect relationships in the anarchic international system. In his interpretation, international actors (mostly states) can give new meanings to foreign policy practices. Thus, in the 1990s, he drew an overoptimistic picture of the linear progression of the development of the international system. He predicted that growing interdependence, homogenisation, the sense of common destiny and self-restraint would, in future, allow for a transfer to a more amicable international system (Wendt 1992; 1999).

At this stage Wendt (like realists) spoke of 'individual' states, being the elements of one and the same 'material' system, in which prevailing ideologies - forming that part of the environment that is changeable - guided the behaviour of all the states and other noticeable actors. These states and actors were endowed with an individual mentality and purpose, and had intentions of their own, but could acquire collective 


Croatian
International
Relations
Review
-
CIRR
-
XXVI (87) 2020,
$6-31$

Croatian

International

Relations

Review

CIRR

XXVI (87) 2020 $6-31$ identity through reproduction and transformation - through intersubjective dynamics at the systemic level (Wendt 1994). Later on, Wendt came to the idea of proposing methodologically holistic sociology as meta-theoretical grounds for IR, having found his new anchorage in quantum physics (Wendt 2015; Little 2018). Pointing out the "relational quality of meaning and practices", Wendt (together with James Der Derian) opted for what they called the relational ontology of consciousness, suggesting that consciousness could be the manifestation of our entanglement with the world and with each other (Der Derian and Wendt 2020). Quanta are neither particles (individua) nor waves and mean superposition (overlapping, adding together of several quantum states). According to 'new' Wendt, neither states nor the EU as a whole should from now on be treated separately as independent agents, because they are 'entangled' as a result of the waves' interference effect (Alekseeva, Mineev, Loshkariov 2016).

Given that the post-modern external policy of the European Union is concentrated to a considerable extent on subjective structures, contexts and non-material aspects of power and influence (such as identity, beliefs and legitimacy), many constructivists - mostly following in Wendt's tracks - insisted on the exclusive ability of the EU (presumably being beyond 'ordinary' states in terms of its socio-cultural development), to transform the international system in a positive (nonconfrontational) way. The NPE concept, mentioned above, was based on understandings that were notably similar to this one.

Manners views the norm-based behaviour of the EU (the promotion of broader norms of peace, democracy and fundamental rights, as well as of the rule of law, social progress, anti-discrimination, sustainable development, and good governance) as a means by which it constructs a benevolent identity for itself, and uses this benevolent identity in its efforts to build a better world. NPE thus presented cannot be regarded as an analytical device: it is not meant to portray the EU and its qualitatively different contra-Westphalian (Manners, Whitman 2003: 399) international role as it is (or used to be), but as it should be or is predetermined to become. It amounts to a statement of the EU's inherent goodness, a goodness that the Union is not supposed to step aside from. An elaboration of this similar strongly normative idea is that it is (or rather should be) the mission of the EU to pursue international relations on 


Croatian
International
Relations
Review
-
CIRR
-
XXVI (87) 2020,
$6-31$

Croatian

International

Relations a multilateral basis, founded on the progressive development of international law, exporting its values of the rule of law and sophisticated governance mechanisms to the international sphere.

The form of constructivist treatment of the EU as described above goes hand in hand with an identity conundrum (a mismatch between how the EU is perceived by its own elites and by others) (Santino Jr. 2013), because it can, in Europe itself, stimulate the ignorance of the widespread (under) appreciation and (mis)understanding of the EU as a global actor by many other inhabitants in the international environment. Additionally, the reality that might be brought into existence by the normative power of the EU is a good or a bad thing depending on the normative stance of the evaluator (Diez, Pace 2007), and not only of the EU itself.

While combining relational ontology with (post)positivist epistemology (as Wendt does), some constructivists may find difficulty in generalising practical mechanisms which are indispensable for bringing about 'social' change ( $\varnothing$ hrgaard 2018: 35-6). At the same time, as an influential example of methodological pragmatism, Wendt's theory opened an analytically productive way to studies, combining constructivism and rationalism more freely in the research of the EU's external relations along broadly understood pragmatic lines - in accordance with the appeal "for a pragmatic turn in research and methodology" (Friedrichs, Kratochwil 2009: 702). For a pragmatist (as well as for Bogdanov with his phenomenological approach), differences between the contexts in which an object of study is examined cause demand to arise for all of the techniques and treatments available, inviting researchers to step over doctrinal and even interdisciplinary boundaries. In consonance with the pragmatic view just described, Petr Kratochvil and Elsa Tulmets have proposed a combination of social constructivism and rationalism to study the EU's external relations, immediately testing the applicability of this model to the relationships of Ukraine, Moldova and Georgia with the Union (Kratochvíl and Tulmets 2010). In their publications, they treat both approaches as equipollent analytical lenses that can be put on or taken off in accordance with the requirements of the context. 


Croatian
International
Relations
Review
-
CIRR
-
XXVI (87) 2020,
$6-31$

Croatian International Relations

Review

CIRR

XXVI (87) 2020, $6-31$

\section{Epistemological relationalism}

Unlike substantionalist IR theories, such as neorealism or neoliberal institutionalism, ontological relationalism orients researchers to the study of objects as embedded in the context of their interlinkages. Within a relational ontology, we deal with the "modifications of being, elements that can be different from each other but that can't truly be separated from each other" (de Ronde and Fernandez Moujan 2017: 7). But Bourdieu, while assuming intentionality-drivenness of human behaviour (Bourdieu, 1977: 9; Marcoulatos 2003), expects field theorists, when studying relational structures, to think epistemologically and to take a break from commonsensical understandings (Singh 2019) because he finds common sense to be inhibiting a clearer comprehension of the world (Bourdieu, Coleman 2019: 373-87). Bourdieu directs a rational-minded researcher towards field research to discover and lay bare structures, existing independently from agents' purpose and awareness. As a case in point, the European External Action Service does not visibly challenge the existence of national diplomacy. Yet its development puts under question the perceived monopoly of the 'normal' states to determine what is to be accepted as 'authentic' diplomacy (Adler-Nissen 2014).

Respective fields can emerge at the transnational level, once there is structural interaction of certain groups of agents, related to transnational goals (problems). Defining states in general (and the EU as a post-modern state in particular) as relational structures is appropriate when considering the forms of the EU participation in international affairs. The EU external relations are being realised in combinations of specific governance modes, first taking shape within the Union, and then appearing in the international deflection. Yet, as pointed out by Didier Bigo with reference to states:

...many sectors of life are not dependent or subordinate to state boundaries and the extent of their territory. They are multiple and transversal to the states (Bigo 2011: 249),

with the construction of a transnational space of institutions and elite practices being presumably inseparable for the agents involved from the promotion of national models of the state. 


Croatian
International
Relations
Review
-
CIRR
-
XXVI (87) 2020,
$6-31$

Croatian

International

Relations

6-31
The substantialist epistemological obstacle (Bachelard 2002: 24-32) could make a researcher opine that the EU promotes its norms abroad with the exact aim for these norms to be adopted by third countries. The Europeanisation of the world at large that the EU is striving for could then be presented as a modernist bureaucratic strategy of managing the globalisation risks of the EU itself through a projection of its own internal order abroad (Medvedev 2008). Bourdieuvian epistemological approach allows experts to regard the meaning of the actions of the EU from a different angle: the Union (or, rather, the people responsible for European institutions) may, not always fully self-consciously or with thoroughly thought-out plans, seek to disseminate ad extra the very model of regulation established within the EU they have become accustomed to - to the point of regarding it as 'natural' and unproblematic. In this way they are inducing an institutional isomorphism between the EU and its international environment, trying to make the latter 'homelike', more like integrated Europe in an organisational sense, and instinctively rendering the surrounding international space habitable for themselves, fashioning it in accordance with the EU's frames of reference.

At the same time, as Bourdieu's is a social critical approach to studying practices, oriented to the study of competition and conflict, his theory gives us no additional opportunity to regard the EU as a meta-organisation, prominent in constructive, cooperative, innovative modes of global governance. For Bourdieu, the adaptability of relational structures remains doubtful. Bogdanov is markedly more optimistic in that respect. The undeservingly half-remembered theory of organisation (tektology) Bogdanov created can be presented as a missing link in the foundation of the present-day relational IR and European studies.

\section{Tektology}

According to the Russian scientist and revolutionary Alexander Bogdanov (1873-1928) (Bogdanov 1984; Gorelik 1983), organisational regularities are the same for objects of any kind (natural, social and psychic). The more the whole differs from the sum of its parts, the higher is its sophistication in organisational terms. At the same time, he regarded organisation not as the end state, but rather as a conversion 


Croatian
International
Relations
Review
-
CIRR
-
XXVI (87) 2020,
$6-31$

Croatian

International

Relations

XXVI (87) 2020 process, resulting from never-ending states of equilibrium transition, conforming to organisational regularities (Tarassov 1998). He also highlighted two basic organising mechanisms for such complexes: construction (implying uniting smaller complexes with all sorts of links) and (self)governance.

Complexes can conjugate, form chain connections, ingressions (a form of catenation through some intermedia) or disingressions (when joined together, activities mutually paralyse each other, leading to the emergence of a 'boundary', or separateness). ${ }^{3}$ Relations between complexes can be integrative (organised), disintegrative (disorganised) or neutral, depending on the purposes realised by those who participate in their constructing. The master regulating mechanism Bogdanov denominates as 'collecting' (podbor in Russian). It can be either conservative or progressive selection (natural or artificial). Darwin's natural selection then becomes a specific instance of this podbor, which he applies to the processes of perdurance and disintegration of organisations of all possible types. Market competition can be singled out as an example of conservative (rule-based) regulative selection mechanism in Bogdanov's understanding. It's selective (discovery) function was indeed highly esteemed by both ordoliberal economists and Friedrich Hayek. Bogdanov expects the workings of podbor to assist in making integrative organisational forms prevail over disintegrative ones in the long run.

Bogdanov is to be recognised as an author of the general systems theory along with Ludwig von Bertalanffy (Gare 2000), an Austrian biologist, who described the organisational principles for open systems with non-equilibrium thermodynamics (metabolically attached to their environment). Earlier than Bertalanffy, Bogdanov already spoke of dynamic or floating counterpoise of organised systems and their 'uncontrolled' environment. In his description, one equiponderant, persistent (self-adjusting, resilient) configuration of a complex aggregate, achieved due to antidromous activities, inevitably gives way to another one. And, unlike Bertalanfy, Bogdanov regards the

3 An illustration for paralysing internal disingression Bogdanov found in the figure of Hamlet, the main character of the play by Shakespeare, whose divided self is forming a 'complex', the components of which are cancelling each other out. The processes of selection, set in motion by a hostile environment, result in the destruction of the Hamlet complex (in the "insanity", then death, of Hamlet himself), but 'system equilibrium' is then restored in the play (and supported by Hamlet's own deathbed will) in the character of Fortinbras, a man of integrity. For a tektological criticism of Hamlet see John Biggard (2016: 16-17) 


Croatian
International
Relations
Review
-
CIRR
-
XXVI (87) 2020,
$6-31$

Croatian International Relations uncoordinated environment as both the source of uncertainty and a challenge for an organisation, relatively autonomous from it.

The general impression at this point is that tektology resonates rather well with the idea of resilience (ability to absorb changes and still exist), capturing "the transformative approach to complex change advocated by the EU" (Tocci 2020: 191), with the EU 2016 Global Strategy (EUGS) elevated into one of the guiding principles for the EU's role in the world (A Global Strategy 2016; Korosteleva, Flockhart 2020).

The similarity of approaches between Bourdieu and Bogdanov can be attributed to the profound influence of Marx on both of them and, in particular, to the Marxian idea that society consists not so much of individuals as of relations. But this similarity should not be overstressed. An important difference is due to the fact that the former is closer to the phenomenological view of the social world and, unlike Bourdieu (Schindler and Wille 2019), is less mistrustful of practitioners' own ability of theory-making, based on everyday experience (Jurt 2017). Empiriomonism (phenomenological Marxism) he developed meant the introduction of a conception of socially organised (contrasted with individual psychic) experience, focused on interactive practices culturally united groups of people would be involved in.

In tektology, the organisational scientific viewpoint is theoretically resharpened to serve in the capacity of a structural grid for an enlightened observer-practitioner, placed inside organisations' dynamic interacting processes. For their scientific study, Bogdanov introduced an assortment of dual concepts: 'activity - antiperistasis', 'assimilation disassimilation', 'conjugation - discontinuity' and other pairs. These pairs are not logical antinomies for him. Somewhat similar to how Bourdieu treated his 'habitus', 'field' and 'capital', Bogdanov sees his dual concepts as researcher's operating tools for logging onto a reference space, with liberally variable observation focuses, in order to study collective 'living' organisations and their interrelations.

For Bogdanov, systems constitute the horizon, determining the limits, within which the real world arises (a fortiori partially) for people to see and transform it constructively, once armed with 


Croatian
International
Relations
Review
-
CIRR
-
XXVI (87) 2020,
6-31

collectivist organisational culture (Bogdanov 1924). Collective deliberation thus becomes the basis for achieving a credible comprehension of reality. At the same time, he does not part with the idea of methodological individualism, as el borated by Max Weber. This idea infers that social phenomena are to be treated through disclosure of how they eventuate out of individual activities. Those, in their turn, are to get their initial exegesis in the intentions, motivating actors. However, Weber notified that:

it is a tremendous misunderstanding to think that an 'individualistic' method should involve what is in any conceivable sense an individualistic spstem of values (Weber 1978: 18).

Bourdieu rejected the usefulness of the organic analogy, which, from Durkheim to Parsons, served as the basis for functionalist theories. For him, states are more likely to belong to relational structures. By default, they cannot be adaptive. Ad maximum, their resistance to (global, external) pressures can be analysed. Bogdanov, in his turn, would sooner agree with wendt about states and quasi-states (like the EU) as social structures preferably being treated as "holographic organisms", invested with collective intentionality (Wendt 2015: 34). At the same time, in contrast with Wendt's position, Bogdanov recognises the limitations of 'social' exchanges between complexes: as part of its life-sustaining activity, in tektological interpretation, each specified 'organism' (re)creates not the overall world, but some particular systematised environment for itself, which is always secondary to the structure of the 'organism' itself. Summing up, the external communication of a complex for Bogdanov, as later formulated by Varela, Maturana and Uribe (1974), is not an information-translation or norms-transferring process, but a process of coordinating the behaviour of entangled complexes via their mutual structural coupling.

The immediate aim of the author of tektology was to come up with practical methods of optimal planning in support of the dynamic equilibrium and resilience of social complexes (organisations), taken within their own environments (which are not two-dimensional 'fields' for him, but multivariate adaptive complexes themselves). The said is closer to understanding resilience "as a set of practices and techniques" (Joseph 2016: 381), relying "on ideas of self-organisation, 


Croatian
International
Relations
Review
-
CIRR
-
XXVI (87) 2020,
$6-31$

adaptation, transformation and survival" (Humbert, Joseph 2019: 215), but has less in common with the advancement of neoliberal governance in particular. ${ }^{4}$ Here we have a reading of resilience, which is adequate for addressing the issues of socio-political adaptation. ${ }^{5}$ In tektology, an organism is actively invading the processes, leading to functional 'media conversion'. The adaptation of the environment to this organism, qua responsive emergent process, results from their coevolutionary transaction (Rispoli 2014: 62).

\section{Conclusion}

Applying IR theories to the study of the international role of the European Union is useful from at least two points of view. On the one hand, the highly complex nature of the $\mathrm{EU}$, and the sophistication of the Union as an object of study, act as challenges to traditional IR, demanding that methods evolve. Pierre Bourdieu's theory of practice and Alexander Bogdanov's tektology, capable of advancing insights into organisational forms and behaviour, seem to be wholesome additions to the ever-widening array of our analytical and methodological tools. On the other hand, unlike the theories of regional integration (such as neofunctionalism, communication theory, and others) that researchers might resort to when analysing the European Union perse, IR theories, in general, prove more helpful in better understanding the EU as an international actor, a transnational agent/subject or a technology of interstate interactions.

With this article the case has been made in particular to employ Bogdanov's tektology for conceptualising the European Union as a meta-organisation, observed in the form of post-state-centrist technology for achieving (presumably) more progressive sociopolitical regime of macroregional proportions without losing the functional integrity of states and societies. On the basis of

4 Those who critically access recent works on resilience are concerned that resiliencethinking may promote neoliberal forms of governmentality and encourage a degree of political passivity (Mckeown and Glenn 2017). Jonathan Joseph and Ana Juncos confirm the broadly neoliberal character of current approaches to resilience in the sphere of global governance (2019).

5 Mark Pelling's classification of adaptation practice identifies three levels of adaptation: resilience, transition, and transformation, distinguished primarily by the extent to which they challenge the status quo. Adaptation as resilience focuses on improving existing practices without questioning underlying assumptions, allowing, among other things, unsustainable or socially unjust practices to continue (Pelling 2012; Hordijk et al. 2014). 
Croatian

International

Relations

Review

$-$

CIRR

$-$

XXVI (87) 2020,

6-31 'possessing' a more sophisticated technology (with its specific constitutive norms) and a set of original 'soft' governance methods, which might prove useful for regulating collective problems and achieving common goals beyond the borders of the EU, European elite is aspiring to cultural (normative) hegemony, to be achieved through institutionalising the EU as a legitimate coordinating centre of global governance, envisioning more regulation. But the neoliberal ideology, externally promoted by the European institutions, contradicts such aspirations: it advocates a minimal state and the replacement of state regulations by market mechanisms. Within the EU, this contradiction is being cross-dissolved with the help of multi-level governance and subsidiarity principle anticipated as its own relational structures. At the same time, the activities of the European governing elite do not present (as yet) cogent evidence of its ability to engage in transboundary deliberative resilience-thinking with other inhabitants of the international milieu. In Bogdanov's terminology, this qualifies as a case of internal cognitive disingression, resulting from the habit to dualistically divide intellectuals from practitioners and the organisers from the organised (Gare 2000: 345), which still allows for the denial of access to rational discourse to the latter.

\section{Bibliography}

Abdelal, R. and Meunier, S., 2010. Managed globalization: doctrine, practice and promise. Journal of European Public Policy, 17(3): 350-67.

Adler, E. and Pouliot, V., eds., 2011. International Practices. Cambridge: Cambridge University Press.

Adler-Nissen, R., ed., 2013. Bourdieu in International Relations: Rethinking Key Concepts in IR, 1st ed. Abington, Oxon: Routledge.

Adler-Nissen, R., 2014. Symbolic power in European diplomacy: the struggle between national foreign services and the EU's External Action Service. Review of International Studies, 40(4): 657-81.

Aggestam, L., 2009. The world in our mind: normative power in a multi-polar world. In: Gerrits, A., ed. Normative Power Europe in a Changing World: A Discussion. The Hague: Netherlands Institute of International Relations. Clingendael European Papers, 5: 25-36, [online], December. 


Croatian
International
Relations
Review
-
CIRR
-
XXVI (87) 2020,
$6-31$

Available at: https://www.clingendael.org/sites/default/ files/pdfs/20091200_cesp_paper_gerrits.pdf [accessed 22 July 2020].

A Global Strategy for the EU's Foreign and Security policy, 2016. An official website of the European Union, [online], June. Available at: https://eeas.europa.eu/sites/eeas/files/eugs_ review_web_0.pdf [accessed 23 July 2020].

Alekseeva, T., Mineev, A. and Loshkariov, I., 2016. «Zemlya smyateniya»: kvantovaya teoriya $\mathrm{v}$ mezhdunarodnyh otnosheniyah? [«Land of confusion»: quantum physic in IR theory?]. MGIMO Review of International Relations, 48(3): 7-16. (in Russian).

Ashley, R., 1984. The poverty of neorealism. International Organization, 38(Spring): 225-286.

Bachelard, G., 2002. The Formation of the Scientific Mind. A Contribution of a Psychoanalysis of Objective Knowledge. Manchester: Clinamen Press.

Bicchi, F., 2006. 'Our size fits all': Normative Power Europe and the Mediterranean. Journal of European Public Policy, 13(2): 286-303.

Biggart, J., 2016. Bogdanov's sociology of the arts. Culture as Organization in Early Soviet Thought: Bogdanov, Eisenstein and the Proletkult. Spherical Book I. Tangential Points Publication Series. Helsinki, Espoo: Aalto University. pp. $1-22$.

Bigo, D., 2011. Pierre Bourdieu and International Relations: power of practices, practices of power. International Political Sociology, 5(3): 225-58.

Boella, G. and van der Torre, L., 2004. Regulative and constitutive norms in normative multiagent systems. Proceedings of the Ninth International Conference on Principles of Knowledge Representation and Reasoning, KR'04, 255-65, Whistler, British Columbia, Canada, [online]. Available at: https://www.aaai.org/Papers/KR/2004/KR04-028.pdf [accessed 22 July 2020].

Bogdanov, A., 1924. O Proletarskoj Kul'ture: 1904-1924 [On Proletarian Culture: 1904-1924]. Leningrad, Moscow: Kniga, [online]. Available at: http://teatr-lib.ru/Library/Bogdanov/ cult/ [accessed 22 July 2020]. (in Russian).

Bogdanov, A., 1984 [1921]. Essays in Tektology: The General Science of Organization, 2nd ed. Seaside, CA.: Intersystems Publications.

Börzel, T. and Risse, T., 2009. Venus Approaching Mars? The European Union as an Emerging Civilian World Power. 


Croatian
International
Relations
Review
-
CIRR
-
XXVI (87) 2020,
6-31

Croatian International Relations Review

CIRR

XXVI (87) 2020, $6-31$
Berlin Working Paper on European Integration, 11 [online]. Available at: https://www.polsoz.fu-berlin.de/polwiss/ forschung/international/europa/Partner-und-OnlineRessourcen/arbeitspapiere/2009-11_Boerzel_Risse.pdf [accessed 10 October 2020].

Bourdieu, P., 1977 [1972]. Outline of the Theory of Practice. Cambridge: University Press.

Bourdieu, P. and Coleman, J. S., eds., 2019 [1991]. Social Theory for a Changing Society. New York: Routledge.

Bulmer, S. and Jonathan, J., 2016. European integration in crisis? Of supranational integration, hegemonic projects and domestic politics. European Journal of International Relations, 22(4): 725-48.

Cooper, R., 2000. The Post-Modern State and the World Order. London: Demos.

Damro, Ch., 2012. Market Power Europe. Journal of European Public Policy, 19(5): 682-99.

Damro, Ch., 2015. Market power Europe: exploring a dynamic conceptual framework. Journal of European Public Policy, 22(9): 1336-54.

Davenport, A., 2013. Marxism in IR: condemned to a realist fate?. European Journal of

International Relations, 19(1): 27-48.

Der Derian, J. and Wendt, A., 2020. 'Quantizing international relations': The case for quantum approaches to international theory and security practice. Security Dialogue, 51(5): 399-413.

de Ronde, C. and Fernandez Moujan, R., 2017. Epistemological vs. Ontological Relationalism in Quantum Mechanics: Relativism or Realism? [preprint]. Available at: http://philsci-archive.pitt. edu/14195/ [accessed 10 October 2020].

Diez, Th. and Pace, M., 2011. Normative Power Europe and Conflict Transformation. In: Whitman, R.G., ed. Normative Power Europe: Empirical and Theoretical Perspectives. Basingstoke: Palgrave Macmillan. pp. 210-225.

Duchene, F., 1972. Europe's Role in World Peace. In: Mayne, R., ed. Europe Tomorrow: Sixteen Europeans Look Ahead. London: Fontana. pp. 32-47

Friedrichs, J. and Kratochwil, F., 2009. On acting and knowing: how pragmatism can advance International Relations research and methodology. International Organization, 63(4): $701-31$.

Gare, A., 2000. Aleksandr Bogdanov and systems theory. Democracy and Nature, 6 (3): 341-59. 


Croatian
International
Relations
Review
-
CIRR
-
XXVI (87) 2020,
$6-31$

Croatian International Relations Review 6-31
Geeraert, A. and Edith Drieskens, E., 2017. Normative Market Europe: the EU as a force for good in international sports governance?. Journal of European Integration, 39(1): 79-94.

Gerrits, A., 2009. Normative Power Europe: Introductory Observations on a Controversial Notion. In: Gerrits, A., ed. Normative Power Europe in a Changing World: A Discussion. The Hague: Netherlands Institute of International Relations. Clingendael European Papers, 5: 1-8, [online], December. Available at: https://www.clingendael.org/ sites/default/files/pdfs/20091200_cesp_paper_gerrits.pdf [accessed 22 July 2020].

Goldthau, A. and Sitter, N., 2015. A Liberal Actor in a Realist World: The European Union Regulatory State and the Global Political Economy of Energy. Oxford: OUP.

Göran, A. and Brunsson, N., 2008. Meta-organizations. Cheltenham: Edward Elgar Publish.

Göran, A., Brunsson, N. and Kerwer, D., 2016. The paradox of organizing states: a meta-organization perspective on international organizations. Journal of Information and Organizational Sciences, 7(1): 5-24, [online]. Available at: http://journal-iostudies.org/sites/default/files/2020-01/ JIOS_7.1_Ahrne-Brunsson-Kerwer.pdf [accessed 23 July 2020].

Gorelik, G., 1983. Bogdanov's Tektology: its nature, development and influence. Studies in Soviet Thought, 26: 39-57.

Hannan, M. T. and Freeman, J. H., 1977. The population ecology of organizations. American Journal of Sociology, 82(5): 929-64.

Hill, Ch., 1993. The capability expectations gap, or conceptualizing Europe's international role. Journal of Common Market Studies, 31(3): 305-28.

Hoffmann, S., 1966. Obstinate or obsolete? The fate of the nation-state and the case of Western Europe. Daedalus: Journal of the American Academy of Arts and Sciences, 95(3): 862-915.

Hooghe, L. and Gary, M., 2001. Multi-level governance and European integration. Lanham, Maryland: Rowman \& Littlefield.

Hordijk, M., Sara, L. M. and Sutherland, C., 2014. Resilience, transition or transformation? A comparative analysis of changing water governance systems in four Southern cities., Environment and Urbanization, 26(1): 130-146.

Humbert, C. and Jonathan, J., 2019. Introduction: the politics of 


Croatian
International
Relations
Review
-
CIRR
-
XXVI (87) 2020,
6 6-31

resilience: problematising current approaches. Resilience, 7(3): 215-23.

Jenkins, R., 1982. Pierre Bourdieu and the reproduction of determinism. Sociolog $\gamma$, 16(2): 270-81.

Joseph, J., 2016. Governing through failure and denial: the new resilience agenda. Millennium: Journal of International Studies, 44(3): 370-90.

Joseph, J. and Juncos, A., 2019. Resilience as an emergent European project? The EU's place in the resilience turn. Journal of Common Market Studies, 57(5): 995-1011.

Juncker, J-C., 2016. State of the Union 2016, [online] 14 September. Available at: https://www.euractiv.com/ section/global-europe/news/soft-power-is-not-enough-foreu-says-juncker [accessed 22 July 2020].

Jurt, P., 2017. Alternative Realism: Interview with cultural and media studies scholar McKenzie Wark on social challenges of the Anthropocene. Global Limit, 4, [online]. Available at: https://www.springerin.at/en/2017/4/alternativerrealismus/ [accessed 11 October 2020].

Kassab, H. S., 2018. Grand Strategies of Weak States and Great Powers. Cham, Switzerland: Palgrave Macmillan.

Keukeleire, S. and Delreux, T., 2015. Competing structural powers and challenges for the EU's structural foreign policy. Global Affairs, 1(1): 43-50.

Korosteleva, E. and Flockhart, T., 2020. Resilience in EU and international institutions: redefining local ownership in a new global governance agenda. Contemporary Security Policy, 41(2): 153-75.

Kratochvíl, P. and Tulmet, E., 2010. Constructivism and rationalism as analytical lenses: the case of the European Neighbourhood Policy. Politics in Central Europe, 6(1):

22-40.

Kreppel, A., 2012. The normalization of the European Union. Journal of European Public Policy, 19(5): 635-45.

Kugiel, P., 2017. End of European soft power? Implications for EU foreign policy. The Polish Quarterly of International Affairs, 1: 59-72.

Little, D., 2018. Entangling the social: Comments on Alexander Wendt, Quantum Mind and Social Science. Journal for the theory of social behaviour, 48(2): 167-176.

Manners, I., 2002. Normative Power Europe: a contradiction in terms?. Journal of Common Market Studies, 40(2): 234-58.

Manners, I. and Whitman, R., 2003. The 'difference engine': constructing and representing the international identity 


Croatian
International
Relations
Review
-
CIRR
-
XXVI (87) 2020,
$6-31$

Croatian International Relations Review 6-31 of the European Union. Journal of European Public Policy, 10(3): 380-404.

Marcoulatos, I., 2003. John Searle and Pierre Bourdieu: divergent perspectives on intentionality and social ontology. Human Studies, 26(1): 67-96.

Mckeown, A. and Glenn, J., 2018. The rise of resilience after the financial crises: a case of neoliberalism rebooted? Review of International Studies, 44(2): 193-214.

Medvedev, S., 2008. Limits of Integration: Identities and Institutions in EU-Russia Relations. Aleksanteri Papers, 2. Helsinki \& Järvenpää: University of Helsinki.

Michalski, A., 2005. The EU as a soft power: the force of persuasion. In: Melissen, J., ed. The New Public Diplomacy: Soft Power in International Relations. New York: Palgrave Macmillan. pp. 124-44.

Murdoch, Z., 2015. Organization theory and the study of European Union institutions: lessons and opportunities. Organization Studies, 36(12): 1675-92.

$\emptyset$ hrgaard, J. C., 2018. International relations or European integration: Is the CFSP sui generis?. In: Tonra, B. and Christiansen, T., eds. Rethinking European Union Foreign Policy. Manchester: Manchester University Press. pp. 26-44. Param, S. and Bilimoria, D., 1997. Isomorphism in organization and management theory: the case of research on sustainability. Organization \& Environment, 10(4): 384-406.

Pavlova, E. and Romanova, T., 2017. Normativnaya sila: teoriya i sovremennaya praktika Rossii i ES [Normative Power: some theory aspects and contemporary practice of Russia and the EU]. Polis (Russian Federation), (1): 162-176. (in Russian).

Pelling, M., 2012. Resilience and transformation. In: Pelling, M., Manuel-Navarrete, D. and Redclift, M., eds. Climate Change and the Crisis of Capitalism: A Chance to Reclaim Self, Society and Nature. London: Routledge. pp. 51-65.

Peters, B. G. and Pierre, J., 2004. Multi-level Governance and Democracy: A Faustian Bargain? In: Bache, I. and Flinders, M., eds. Multi-level Governance. Oxford: Oxford University Press. pp. 75-89.

Regilme Jr., S .S. F, 2013. It Takes Two to Tango: A Constructivist Analysis of EU-ASEAN Interregional Relations. In: Boening, A., Kremer, J.-F. and van Loon, A., eds. Global Power Europe, vol. 2. Berlin, Heidelberg: Springer-Verlag. pp. 237-52.

Rispoli, G., 2014. Teorii sistem i e'volyucionny'e transakcii v kontekste ucheniya A.A. Bogdanova [Systems theories and evolutionary transactions after A.A. Bogdanov]. Russian 


Croatian
International
Relations
Review
-
CIRR
-
XXVI (87) 2020,
6-31

Journal of Philosophical Sciences, 12: 50-65. (in Russian). Schindler, S. and Wille, T., 2019. How can we criticize international practices? International Studies Quarterly, 63(4): 1014-24.

Schneider, V., 2015. Relationalism in Political Theory and Research. Przegląd Politologiczny, 4: 191-206.

Singh, S., 2019. How should we study relational structure? Critically comparing the epistemological positions of social network analysis and field theory. Sociolog p, 53(4): 762-78.

Smith, M., 2004. Toward a theory of EU foreign policy-making: multi-level governance, domestic politics, and national adaptation to Europe's common foreign and security policy. Journal of European Public Policy, 11(4): 740-58.

Strezhneva, M., 2018. Ekonomicheskij i valyutnyj sopuz v Evrope: problemy effektivnosti i legitimnosti [Economic and Monetary Union in Europe: the Problems of Effectiveness and Legitimacy]. Moscow: IMEMO. (in Russian).

Tarassov, V., 1998. Tektologiya A.A. Bogdanova i neoklassicheskaya teoriya organizacij - predvestniki ery reinzhiniringa [Tektology by A.A. Bogdanov and Neoclassical Theory of Organisations as Forerunners of the Re-engineering Era]. Software \& Systems, 2: 43-8, [online]. Available at: http://www.swsys.ru/index. php?page=article\&id=989\&lang=en [accessed 12 October 2020]. (in Russian).

Tautz, J. and Heilmann, H. R., 2008. The Buzz About the Bees: Biology of a Superorganism. Berlin: Springer.

Tocci, N., 2007. Profiling Normative Foreign Policy. CEPS Working Document 279. Brussels: Centre for European Policy Studies.

Tocci, N., 2020. Resilience and the role of the European Union in the world. Contemporary Security Policy, 41(2): 176-94. Varela, F., Maturana, H. and Uribe, R., 1974. Autopoiesis: The Organization of Living Systems, Its Characterization and a Model. Biosystems, 5(4): 187-96.

Vasfilov, D., 2014. A systemic analysis of the interaction between Russia and the European Union in the Post-Soviet Space. International Organisations Research Journal, 9(3): 31-46.

Veebal, V. and Markus, R., 2018. European normative power during Ukrainian-Russian Conflict. Baltic Journal of Law \& Politics, 11(1): 1-20.

Wacquant, L., 2005. Habitus. In: Becket, J. and Zafirovski, M., eds. 
Croatian

International

Relations

Review

-

$-$

XXVI (87) 2020,

6-31
International Encyclopedia of Economic Sociolog $\gamma$. London: Routledge. pp. 317-21.

Weber, M., 1978. Economy and societ $\gamma$, vol. 1. Berkeley: University of California Press.

Wendt, A., 1992. Anarchy is what states make of it: the social construction of power politics. International Organization, 46(2): 391-425.

Wendt, A., 1994. Collective identity formation and the international state. American Political Science Review, 88(2): 384-96.

Wendt, A., 1999. Social theory of international politics. Cambridge: Cambridge University Press.

Wendt, A., 2015. Quantum Mind and Social Science: Unifying Physical and Social Ontology. Cambridge: Cambridge University Press.

Wohlforth, W., 2008. Realism. In: Reus-Smit, C. and Snidal, D., eds. The Oxford Handbook of International Relations. New York: OUP. PP. 131-49.

Wolfers, A., 1962. The Goals of Foreign Policy. Chapter five in: Discord and Collaboration: Essays on International Politics. Baltimore: The Johns Hopkins Press. Pp. 67-80. 